\title{
Epizootologic Potential of Certain Natural Foci Infections in Northeastern Armenia
}

\author{
Arsen Manucharyan* \\ Laboratory of Epizootology, Ectoparasitology and Entomology, RA MOH, NCDCP SNCO, Reference Laboratory Center branch, \\ Yerevan, Armenia
}

\section{Objective}

The objective of this study was to analyze the epizootic potential of four areas of Tavush Marz.

\section{Introduction}

Tavush Marz, in northeastern Armenia, occupies 9,1\% of its territory. In recent years in this area either no surveys were conducted or they were incomplete. Tavush Marz is a tourism center as well as a border Marz with strategic importance. The presence of tularemia was first confirmed in 1949 in Noyemberyan. Natural foci of tularemia are located in forest zones where Sylvemus uralensis and its flea vectors are the source of infection.

\section{Methods}

Tests were conducted in four areas of Tavush Marz. Materials for laboratory analyses were collected via sampling from animal populations and their nests; insect traps, nets, aspirators were used as well. Collected rodents, fleas and mosquitoes were tested on the presence of natural foci especially dangerous infections. The acquired data with coordinates of collection sites were included in the geographic database.

\section{Results}

The first detection of the Aedes albopictus species of Culicoidea subfamily in Armenia was on the border between Noyemberyan and Georgia in 2016; this is a vector of especially dangerous infections and arboviruses. The presence of the mosquito was confirmed in 2017 and it makes up $13.5 \%$ of the mosquitoes collected in the northeast. It is capable of transmitting the chikungunya, Dengue, and West Nile viruses. Since the end of 2015, we have recorded a significant increase in carriers and vectors, mainly S. uralensis, Microtus socialis, and ectoparasites specific to them. In October 2016 six cases of infection with tularemia were recorded in the village of Tsakhkavan in Tavush region and in Bagratashen Village of Noyemberyan region in 2017.

\section{Conclusions}

Analysis of the density of rodents and vectors, as well as their typical ectoparasites leads us to conclude that there are favorable conditions for the spread of not only tularemia but also other natural foci infections and that a comprehensive and regular epizootological survey is required to control this situation.

Average Density of Sylvemus uralensis per Hectare

\begin{tabular}{|c|c|c|c|c|}
\hline $\begin{array}{c}\text { Region/ } \\
\text { Year }\end{array}$ & 2013 & 2014 & 2015 & 2016 \\
\hline Noyemberyan & 10,6 & 12,8 & 23,4 & 30,4 \\
\hline Tavush & 10,5 & 18,7 & 30,9 & 45,4 \\
\hline Ijevan & 8,1 & 10,7 & 12,9 & 20,3 \\
\hline
\end{tabular}

Average density of M. socialis per hectare

\begin{tabular}{|c|c|c|c|c|}
\hline $\begin{array}{c}\text { Region/ } \\
\text { Year }\end{array}$ & 2013 & 2014 & 2015 & 2016 \\
\hline Noyemberyan & 12,6 & 14,9 & 24,9 & 33,4 \\
\hline Tavush & 8,5 & 11,5 & 20,9 & 38,4 \\
\hline Ijevan & 5,6 & 10,5 & 18,9 & 24,4 \\
\hline
\end{tabular}

Fleas characteristic to $\mathrm{S}$. uralensis and $\mathrm{M}$. socialis

\begin{tabular}{|c|c|c|c|c|}
\hline $\begin{array}{c}\text { Flea species/ } \\
\text { Year }\end{array}$ & 2013 & 2014 & 2015 & 2016 \\
\hline L. taschenbergi & 0 & 2 & 10 & 4 \\
\hline Ct. bogatschevi & 20 & 18 & 8 & 218 \\
\hline Ct. secundus & 3 & 10 & 14 & 60 \\
\hline N. consimilis & 0 & 10 & 11 & 78 \\
\hline L. bidentata & 0 & 2 & 0 & 1 \\
\hline Ct. acuminatus & 0 & 0 & 7 & 3 \\
\hline
\end{tabular}

\section{Keywords}

epizootologic potential; natural foci; tularemia

\section{*Arsen Manucharyan}

E-mail: arsen.manucharyan.1976@mail.ru 